\title{
ETHNOBOTANICAL SURVEY OF PLANTS USED AS AMULETS AMONG THE BANEN ETHNIC GROUP IN NDIKI SUB-DIVISION (CENTRE REGION OF CAMEROON)
}

\author{
Madeleine Johnson ${ }^{1,2}$, Evariste Fongnzossie ${ }^{3}$ \\ ${ }^{1}$ Laboratoire TransCell Lab, Faculté de médecine Xavier Bichat, Rue Henri Huchard, PO Box 416 - 75870, France \\ ${ }^{2}$ University of Hamburg, Biocentre Klein Flottbek \& Botanical Garden - BEE- Ohnhorstrasse 18, D-22609 Hamburg, \\ Germany \\ ${ }^{3}$ University of Douala, Advanced Teacher's Training School for Technical Education, PO BOX 1872, Douala, \\ Cameroon
}

Link to this article: https://doi.org/10.11118/actaun202068040741

Received: 8. 3. 2019, Accepted: 14. 7. 2020

To cite this article: JOHNSON MADELEINE, FONGNZOSSIE EVARISTE. 2020. Ethnobotanical Survey of Plants Used as Amulets Among the Banen Ethnic Group in Ndiki Sub-Division (Centre Region of Cameroon). Acta Universitatis Agriculturae et Silviculturae Mendelianae Brunensis, 68(4): 741-753.

\begin{abstract}
An ethnobotanical survey was carried in Ndiki sub-division of the Central Region of Cameroon to collect information on the use of plants in the manufacture of amulets among the Banen ethnic group. Focus group discussions and interviews were carried out from 2004 to 2010 and from 2013 to 2015 with a total of 50 respondents (34 men and 16 female) to gather information about local names of plants used, type of management (wild/cultivated), availability (common, sporadic, rare), existing threats, part(s) used, preparation methods, effects of amulets, associated taboos/beliefs, etc. A total of 11 plant species were recorded as used as amulet. They include Aframomum melegueta (Zingiberaceae), Cissus aralioides (Rubiaceae), Costus afer (Zingiberaceae), Euphorbia kamerunica (Euphorbiaceae), Imperata cylindrica (Poaceae), Kigelia Africana (Bignoniaceae), Morinda morindoides (Bak) Milne-Redh (Rubiaceae), Ornithogalum sp. (Amaryllidaceae), Pentaclethra macrophylla (Mimosaceae), Platycerium angolense (Polypodiaceae), Trachyphrynium braunianum (Maranthaceae). The amulets are used to protect people and their property, inflict sentiments of respect and fear. In case of violation, the perpetrator faces diverse punishments including suddenly seeing a big snake, hearing of a deafening scream in their ears, various evil and skin diseases. He can be healed upon confession of his wrongdoing to the owner of the amulet.

This study shows that the traditional knowledge on amulets is an important part of the living habits and culture of Banen people who still have a strong belief in their efficacy.
\end{abstract}

Keywords: plants, amulet, ethnobotanical survey, Banen, Ndiki, Cameroon

\section{INTRODUCTION}

Amulets are objects believed to protect its owner from danger or harm (Gonzalez-Wippler, 1991). The word amulet comes from low Latin - amuletum, which means remove, repel, drive. Upon closer investigation, it appears to originate from the Arabic language - hamâlet of hamala, and means wear (Cabaton, 1909). In fact, it is from the East that the use of amulets spread to Europe. This word was adopted in the French language in the $16^{\text {th }}$ century and in the German language in the $18^{\text {th }}$ century (Hoffmann-Krayer et al., 1927-1942). In the past as well as today, when a person is unable to 
fight against emotional, physical and psychological discomforts in its various aspects (disease, sorrow, difficulties of all kinds), the person may try to remove or neutralize it with plants, words, signs and objects to which he attributes a supernatural power. This use of amulets and incantations by traditional medical practitioners has been reported in several parts of the world (Bhuiyan et al., 2013; Humayun Kabir et al., 2013; Pieroni et al., 2011) and people have believed they could protect them from harm, bring good luck, or drive away evil spirits.

In all societies of the world and in Cameroon in particular, the safety of people and their property is a serious priority. For this, there are administrative means, such as the police, judiciary and penitentiary systems to manage different situations in cases of non-compliance, breach or offense. These means are less convincing and ineffective to the Banen people of Cameroon. In most rural societies and in particular in Banen society, laziness and contempt cause some people to engage in devious practices, such as theft to appropriate the property of others and witchcraft to inexplicably destroy their objects of desire. It is said of those who try to harm others by witchcraft that they have a "big heart" or "moláàmaà monáàna" and "long, greedy eyes" or "Meeàse matatanc." There are reports indicating that the context of poverty and widespread corruption in Cameroon has hampered access to justice (Njupouen, 2005). For these reasons, the Banen people established ritual practices of using "amulets" or "Meéle" to overcome these malicious actors. Made from whole plants, parts of plants and the relics of some animals, the amulets represent a successful model of sustainable, traditional education and autonomously organized justice.

Based on strong cultural and religious beliefs, this traditional system seems to be highly effective against theft and wickedness. The principle of this method of education is based on fear and respect for traditional local beliefs, the power of curses and death. Currently, the power of traditional authorities within the community is weakening, most of rituals are no longer respected; but the amulet is an exception that is still revered, according to the local people. These amulets cause offenders to behave and understand that jealousy is an evil. These a priori passive items become very aggressive after adjuration or "óyómena" -reciting words to invoke curses while chewing and spitting the seeds of Aframomum melegueta, according to the Banen people.

It is wildly known in Africa that plants contribute to food security, therapeutic needs, and the welfare of societies. They can also be used for ritual and magical purposes. Hence, the folk knowledge of people about their environment still deserves more detailed research in Africa in general and Cameroon in particular. In fact, Cameroon is among the countries in Africa with a rich endowment in plant and cultural diversity. So far, ethnobotanical investigations in the country have put great emphasis on surveying medicinal plants and wild edible plants among different tribal groups. Spiritual uses of plants have only been poorly documented.

As mentioned by Cotton (1996), three main approaches exist in the study of traditional botanical knowledge: the utilitarian approach focusing on the gathering of information about the use value of plants in traditional material culture, the cognitive approach based on plants perception by people in different sociocultural contexts and the ecological approach emphasizing on plant management, exploitation as well as interspecific relations and relationships between plants and local environment. This study uses the abovementioned framework of Cotton (1996) and the conceptual framework of the Intergovernmental Platform on Biodiversity and Ecosystem Services (IPBES) that identifies three inclusive elements in the interaction between human societies and the non-human world (Pascual et al., 2017): nature, nature's benefits to people, and a good quality of life. The main goal is to document the traditional knowledge of using plants as amulets among the Banen people and the associated power, beliefs and benefits. Specifically, the study assesses plants species used in the manufacture of amulets, the mode of preparation of amulets. It also describes the local people perception of the roles of the amulet, their effects and the treatment of disorders and diseases caused by amulets.

\section{MATERIALS AND METHODS}

\section{Study Site}

The Banen people are located approximately $60 \mathrm{~km}$ from the coastal region in southern Cameroon, straddling the central and littoral regions of the country (Fig. 1). This territory is situated at longitude $10^{\circ} 33^{\prime}$ West and $11^{\circ} 11^{\prime}$ East and latitude $4^{\circ} 5^{\prime}$ North and $4^{\circ} 35^{\prime}$ South. The Banen's habitat forms an elongated rectangle slanting northeast/southwest and spans a total space of about 5,000 $\mathrm{km}^{2}$. The Destiny (migratory waves) divided them by situating a portion of them in the Littoral Region called "Efómbó" in the Yingui and Bonépopa subdivisions of the Nkam division; and the other portion called "Ndiki" in the Central Region of Cameroon in the Ndikiniméki, Nitoukou, Makénéné and Nkon yambeta subdivisions of the Mbam and Inoubou division (Johnson, 2013; Johnson, 2017). This territory is limited to the north and northwest by the Bamileke and Bamum; to the west by the Mbang, Bakem, the Babon and the Balondo; south by the Babimbi; southwest by the Bassa and east by Bafia (Mahend, 1967). Although geographically separate, the two Banen groups are still united by their language, religion and customs. In this study, we will have to focus only on the part of "Ndiki". 
The study area comprise about 46 villages and is inhabited not only by the Banen but also by the Bamiléké, Bamoun, Bamenda and also by Hausa immigrants from western and northern Cameroon and Nigeria, who practice agriculture, trade and cattle breeding (Iyebi-Mandjeck, 1985; Johnson, 2013/2017).

Phytogeographically, the Banen territory is located in the Guineo-Congolese tropical rain forest area. Specifically, the territory is located in a transition zone between the semi-deciduous forest and the Guinean savannahs (Letouzey, 1968). This allows the Banen people to enjoy special climatic conditions characterized with constant temperatures (average $24^{\circ} \mathrm{C}$ ), sufficient rainfall with annual precipitations of about $2000 \mathrm{~mm} / \mathrm{year}$ in the forest area and $1500 \mathrm{~mm} / \mathrm{year}$ in the savanna area. The attraction of this area is that, different types of vegetation can be found in a very small area, which represents a rich floral diversity: primary rainforest, secondary forest, woody savannah and grassland.

The Banen practice "slash and burn" agriculture with a bimodal annual farming cycle, which is entirely dependent on the rainfall pattern. Hunting and fishing are also part of the activities of the Banen people.

\section{Selection of Respondents}

Ethnobotanical data were collected during stays in situ in the Ndikinimeki, Nitoukou and Makénéné localities, between 2004-2010 and 2013-2015, from a total of 50 respondents, purposively selected with the help of traditional leaders and based on their willingness to participate. All the respondents were well-known in the community for their long practice in manipulating amulets. Interviews were inclusive of all genders and age groups. Their age ranged between 12 and 80 years; 34 were men and the rest were women.

\section{Ethnobotanical Data Collection}

Ethnobotanical data were collected through visiting the respondents to document the indigenous knowledge of using plants in the preparation of amulets. Individual interviews were conducted to gather information on name, age, sex, level of education, occupation, and ethnicity of respondents. Moreover, respondents were asked about local names of plants used, type of management (wild/cultivated), availability (common, sporadic, rare) in the area, whether their occurrence is threatened or not, plant part(s) used, whether combinations of plants are used or if any single plant is used, preparation methods, associated taboos/beliefs, etc. The interviews were followed by field walks, which gave an opportunity for more discussions with respondents and practical identification of traditionally used plants in their natural environment. This was also an opportunity to observe the rituals and gather information on which plant species were used to protect which property and why the Banen people are so afraid of amulets.

Interviews and discussions were conducted in local languages. This methodology has been successfully used by several researchers including Betti (1994), Betti and Lejoly (1999) and Johnson (2013, 2017).

Plants named in the interviews were identified in situ in the field using available floras (Vivien and Faure, 1985; Wilks and Issembé, 2000; Letouzey, 1982; Thirakul, 1983). For each reported plant species, a specimen was collected, pressed, dried, and their identification was confirmed at the Cameroon National Herbarium of Yaoundé (YA). The voucher specimen was kept at Millennium Ecological Museum Herbarium.

To allow true collaboration of respondents, the nature of this research was carefully explained to the community members and interviews were only conducted after obtaining prior informed oral consent according to the Code of Ethics of the International Society of Ethnobiology (ISE 2006).

\section{Data Analysis}

Simple descriptive statistics were applied to represent and list the number and percentage of species of plants used; parts used; modes of amulets preparation and use.

Finally, the key language was appreciated by Professor Ludwig Gerhardt, an expert in linguistics from the University of Hamburg, the experts of the Committee for the Development of Tunen Language (CODELATU) and those of the Cameroon Association for Bible Translation and Literacy (CABTAL). The vernacular names of the plants and expressions were recorded and assessed. These names enabled to observe whether there is a link between the names of plants, the plant itself and their ritual use.

\section{RESULTS}

\section{Plants Used in the Manufacture of Amulets}

From this survey, 11 plant species were recorded as used in the preparation of the amulet (Tab. I). They belong to 11 families and 11 genera.

Different life forms and plant parts are used: shrubs, trees, lianas, herbs and epiphytes. Parts used are leaves, seed, barks, fruit, branch, stem and sometimes the entire plant. The plants are used fresh or dried (integument, stem, fruit) to make the amulet.

The plants used in the manufacture of amulets are collected in different habitats that occur in the region of Ndiki: forest, savanna, plantations, swamp, garden/field and fallow. 
I: Plants used as amulets by Banen and frequency of citation

\begin{tabular}{|c|c|c|c|c|c|}
\hline No. & Scientific name & Family & Vernacular name & Part used & $\begin{array}{c}\text { Frequency } \\
\text { of citation (\%) }\end{array}$ \\
\hline 1 & Aframomum melegueta & Zingiberaceae & Helóaà háà basaà & seeds & 100 \\
\hline 2 & Cissus aralioides & Vitaceae & Ekáláànjá & Stem vine & 50 \\
\hline 3 & Costus afer & Coastaceae & Muandó & Stem & 100 \\
\hline 4 & Euphorbia kamerunica & Euphorbiaceae & Mskáls & Stem pith & 70 \\
\hline 5 & Imperata cylindrica & Poaceae & Hándjó & Entire plant & 50 \\
\hline 6 & Kigelia africana & Bignoniaceae & Onjómó & Fruits & 80 \\
\hline 7 & Morinda morindoides & Rubiaceae & Nálámbaà náà meeàse & Ripe yellow fruit & 40 \\
\hline 8 & Ornithogalum sp & Amaryllidaceae & Nányaànáàa náà bátaàma & Entire plant & 90 \\
\hline 9 & Pentaclethra macrophylla & Caesalpiniaceae & Bókómbóló & Empty fruit pod & 100 \\
\hline 10 & Platycerium angolense & Polypodiaceae & Áfaàfáàláana & Entire plant & 40 \\
\hline 11 & Trachyphrynium braunianum & Marantaceae & Ándeta & A leaf of the plant & 30 \\
\hline
\end{tabular}

\section{Role of Amulets}

The types of amulets and their role depend on the plant species used and the incantations practices associated (Tab. II). The dual effect of the amulet is to scare and to punish by:

- Creating fear: in this case, the amulet is used or installed without being adjured. Only the owner knows s/he has not "energized" the amulet. For thieves or jealous people, it is not obvious.

- Punishment: in this case, the amulet is placed on the elements to be protected after adjuration. Even in this case, only the owner knows what he did and said. Nothing is naturally visible to the wicked, since all that is used is words and saliva.

Overall, four types of protection through the amulets were mentioned by the informants:

- The protection of fruit trees bearing ripe fruits When the fruits on a tree or "bóláàaà bóà tutamatama" are ripe, the owner sets an amulet near the base of the tree "indine yiù bóláàaà" to protected it. The amulet is made visible to all by hanging it on a well-cut stick or "ombanjáà woà ómbókótó” before planting it in the ground.

- The protection of various elements deposited at a particular place: for example, when someone sells consumer products in front of his house, an amulet is placed there, so he does not need to watch out all the time. The customer is obliged to report when they arrive to be served. In this case, the amulet can be exposed for potential thieves to see (Fig. 5).

- The protection of plantations or cultivated fields. In this case, amulets are used against the envious,

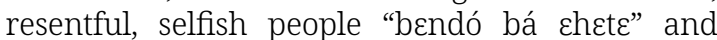
witches "bendó bá bibune" approaching or watching the plantation "Etóbótóbó” or "Embóàma" with devious intentions. For protection, the amulet can be placed in the four corners of the plantation or field.
- The protection of compound/house/people In this case, the amulet is placed at the entrance of the compound/house to protect the house or "miíme" and the persons or "bendó" living there against envious, resentful, selfish people.

\section{Forms of Adjurations}

When making the amulet, the formula given during the adjuration for the protection of property is always the same, but it differs slightly with the type of the elements that must be protected.

Before adjuring the amulet, fruit of Aframomum melegueta is preadjured by the following formula of chewing and spitting seeds while reciting this:

“...á híémie helóa he basaà... cúí ...ó nuáka... cúí..ó nuáká háhá óà me Meeàle... cúí ...óà má me nó ákáná me bekáàaàkená háha... cúí ... عlóa yáè búámáaà Bóla ótáta... cúí...” meaning “... my fruit ... tzu (spitting) ... I invoke you to act ... tzu ...on this amulet that I'm making ... tzu ... in order to protect my property... tzu".

Concerning the items described in the protection of fruit trees bearing ripe fruits and in the protection of various elements deposited at a particular place, the formula would be as follows:

“...á búámáá bóla... cúí ...me ndó ánjó yekenaà... cúí...elóa yá bendó bá búíbi... cúí ...átá eyánáà á nánó ítíele... cúí ...ó wáàaàyá hálcna... cúí (Adjuration of goods)”, meaning “... my property ... tzu ... I will protect you ... tzu ... against thieves ... tzu ... and against anyone who touch you ... tzu ... I order you to punish ... tzu ".

In case of protection of plantations or cultivated fields and in the protection of compound/house/ people, the formula would be:

“...á yámáá mime/embóàma.... cúí ....me ndó án†ó yekena... cúí

عlóa ye bendó bá ehete na Bendó bá bíbúne ... cúí

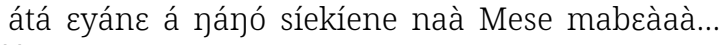
cúí ... 
II: Various roles of amulets and processing method

\begin{tabular}{|c|c|c|}
\hline $\begin{array}{l}\text { Amulet } \\
\text { type }\end{array}$ & Plant species used & Mode of processing \\
\hline 1 & $\begin{array}{l}\text { Aframomum melegueta } \\
\text { (Fig. 1, Fig. 2) }\end{array}$ & $\begin{array}{l}\text { The amulet is adjured by chewing the seeds to mix them with saliva, then spitting } \\
\text { them out while pronouncing the words of adjuration. A total of nine seeds } \\
\text { are used. According to the Banens, an amulet would have no effect unless it is } \\
\text { accompanied by this ritual. }\end{array}$ \\
\hline 2 & $\begin{array}{l}\text { Cissus aralioides } \\
\text { (Fig. 3, Fig. 4) }\end{array}$ & $\begin{array}{l}\text { To make the amulet, one must cut a long climbing stem without leaves. If } \\
\text { necessary, you can also use other species of Cissus (eg. Cissus quadragularis) } \\
\text { which can perform the same function. Long stem vine is rolled so that it forms } \\
\text { a cylindrical coil. According to the Banen, if this amulet is placed in farm of near } \\
\text { any good to protect, the thief or robber who comes will suddenly see a big snake } \\
\text { if they touch someone's goods. }\end{array}$ \\
\hline 3 & $\begin{array}{l}\text { Costus afer } \\
\text { (Fig. 5, Fig. 6) }\end{array}$ & $\begin{array}{l}\text { To make the amulet, one can use the entire plant (rooted) or only the stem with } \\
\text { a few leaves. This type of amulet can be used in the protection of residence and } \\
\text { farms. In general, it is used to protect the family compound after a birth or before } \\
\text { a very important event (rituals), where the presence of many persons is expected. } \\
\text { The amulet preparation consists of an invocation of various kinds of evil on any } \\
\text { perpetrator of witchcraft of any bad practices. }\end{array}$ \\
\hline 4 & $\begin{array}{l}\text { Euphorbia kamerunica } \\
\text { (Fig. 7, Fig. 8) }\end{array}$ & $\begin{array}{l}\text { The plant is cut an placed on the object to protect, usually fruit tres while making } \\
\text { incantations. The amulet causes various evils and skin infections on any perpetrator. }\end{array}$ \\
\hline 5 & $\begin{array}{l}\text { Imperata cylindrical } \\
\text { (Fig. 9, Fig. 10) }\end{array}$ & $\begin{array}{l}\text { To make the amulet, the plant must simply be uprooted as bundle and tied so as } \\
\text { to form a knot at the top. Tying the knot is a symbol of locking the person who has } \\
\text { done something wrong into a vicious circle full of misfortunes. It brings various } \\
\text { evils and skin infections on the perpetrator. }\end{array}$ \\
\hline 6 & $\begin{array}{l}\text { Kigelia Africana } \\
\text { (Fig. 11, Fig. 12) }\end{array}$ & $\begin{array}{l}\text { To make the amulet, only the fruit is used. It can be used in full or half. According to } \\
\text { the Banen, the amulet causes various evils and skin infections on the perpetrator. }\end{array}$ \\
\hline 7 & $\begin{array}{l}\text { Morinda morindoides } \\
\text { (Fig. 13, Fig. 14) }\end{array}$ & $\begin{array}{l}\text { The ripe, yellow fruit is used to make the amulet. This fruit has 6-7 holes along its } \\
\text { surface. According to the Banen these holes symbolize the "eyes". These eyes are } \\
\text { opened on the protected objet. The fruits can be placed at each corner of a field or } \\
\text { plantation to protect the farm against witchcraft and thieves. In case of offense, it } \\
\text { brings various kinds of evil on the perpetrators and sometimes on their offspring. }\end{array}$ \\
\hline 8 & $\begin{array}{l}\text { Ornithogalum sp } \\
\text { (Fig. 15) }\end{array}$ & $\begin{array}{l}\text { To make the amulet, one can use the entire plant (rooted) or only one leave. } \\
\text { According to the Banen, the plant, associated with incantations can cause skin } \\
\text { inflammations to any perpetrator. }\end{array}$ \\
\hline 9 & $\begin{array}{l}\text { Pentaclethra macrophylla } \\
\text { (Fig. 16) }\end{array}$ & $\begin{array}{l}\text { The empty pod is used to make the amulet. This amulet is used to protect property. } \\
\text { P. macrophylla causes various kinds of evil against the perpetrators and sometimes } \\
\text { on/against their offspring. According to the Banen, it can be placed at the main } \\
\text { entrance of the house so that all who enter with bad intentions are neutralized } \\
\text { and punished immediately. }\end{array}$ \\
\hline 10 & $\begin{array}{l}\text { Platycerium angolense } \\
\text { (Fig. 17) }\end{array}$ & $\begin{array}{l}\text { To make the amulet, the whole plant is needed. It is easily detached from the shaft } \\
\text { on which it is embedded. It is used to protect consumer goods. P. angolense causes } \\
\text { various kinds of evil on the perpetrator. }\end{array}$ \\
\hline 11 & $\begin{array}{l}\text { Trachyphrynium braunianum } \\
\text { (Fig. 18) }\end{array}$ & $\begin{array}{l}\text { A leaf is twisted so as to form a funnel-shaped container, which is then fixed on } \\
\text { a pole planted and pointed to the element or object to be protected. The Banen } \\
\text { believe that this type of amulet is the most dangerous of all, because it affects all } \\
\text { people once adjured, even its owner. The amulet causes to all who approach the } \\
\text { objet, intense, deafening screams in their ears. }\end{array}$ \\
\hline
\end{tabular}

ó weyá hálena... cúí .

“... my house/field ... tzu... I am protecting you against resentful people ... and witches ... tzu ... look out against anyone with bad intentions ... tzu I command you ... to punish tzu ...”

Note: When listening or reading "tzu”, the adjurer spits the chewed seeds on the amulet.

\section{Plant Knowledge and Perception of the Amulets by Respondents}

All Banen people in the study area recognized and identified inventoried plants as components of amulets. Among those who were inhabitants of Douala, Yaoundé and Ngaoundéré, 80\% were able to identify all the plants with local names and give their function as amulets. The rest could not name the plants by local name but knew very well about their function. 
The survey indicated that most of the Banen prefer the use of plants to protect them and/or their property, instead of relying on the governmental or ecclesiastical system. According to the Banen, amulets are more discreet, respected, powerful, dangerous and free of charge.

They believe that within the judiciary system, lawsuits are often won based on which side is able to defend themselves better, but not based on who is right. This judiciary method is not only costly, but is also time consuming and susceptible to corruption. In the cases where a court case has been won, it is still necessary to obtain the execution of the decision. This however, is not always easy, and many steps can separate the decision from its effective implementation. Unlike the amulet, the Banen are not very afraid of prison. For them it is just a stay away from home. They would prefer to be stopped by the police than falling into the yoke of the amulet. This is established by what Sil Bagnam, a dignitary in the chiefdom of Ndiki-village said during one of our multiple interviews:

"The prison is nothing...and with a little luck and means you can always negotiate... The amulet knows no negotiation or pity ...it does not forgive".

The amulet is of great value to the Banen people. Its power lies in its discreteness, incorruptibility, dangerousness and unforgiveness. The amulet's power is discrete, since no one outside the owner knows information about the adjuration on the plant used. It is not corruptible, since it will never bear false witness if there is an offense. It is very dangerous and does not forgive, contrary to what the doctrine that Christianity teaches. However, the victims has the opportunity to recognize their fault and be forgiven. The intention of the amulet is to deter the repetition of the fault and enable everyone to live in peace.

With the amulet hanging at the entrance of the family compound, the Banen people feels better and sleeps better. The amulet is reassuring and calming. For the majority of the population, God is believed to be a creator who has given power to the components of nature, such as plants, so that man can make use of it. The confirmation of this statement is from Ofakem, a stakeholder and trader in the village Nefante who said: "God is where he is and I do not see him, but my plants in the contrary, I see and I use them".

It appears that the effectiveness of the amulet depends on the adjuration with the seeds of A. melegueta. Its effectiveness is independent of the shape, size, length, and color of the plant.

The species used to make amulets can be gathered in the wild or easily cultivated. All amulets are used by both women and men, excluding $M$. morindoides, which is only used by women in the fields of food crops. They represent a successful model of sustainable traditional education.

\section{The Effects of Amulets}

According to the Banens, in cases of noncompliance, the majority of amulets will produce repeated occurrences of various diseases and skin inflammations. Amulets that produce other effects include the amulet made of $T$. braunianum, which produces a deafening sound in the perpetrator's ears, and the amulet made of $C$. aralioides, which conjures the sudden appearance of a big snake. When amulets are used to protect fields and plantations, people report a recurrence of accidents of various kinds, complicated diseases and even death of the guilty persons and members of their family. For the amulet made of $T$. braunianum, the owner destroys it by holding it above the fire and is very careful before touching its remains. In the case where the consequences of the amulet come to manifest, the Banen will say: "Meeàle má ná wáyá hálána” to mean: the amulet trapped him.

\section{The Treatment of Disorders and Diseases Caused by Amulets}

To cope with the effects of the amulet, the guilty person must present himself to the owner of the amulet to confess his wrongdoing. This is imperative because the owner is the only one able to give the first solution. It is only then, if the owner decides to help that the guilty will begin with the treatment. If the owner decides to help, the amulet will be first burned and the ash will be scattered in front of a river. Thus, according to the Banen tradition, all misfortunes and diseases of the victims disappear with the flowing waters. At this time, the Banen will say: "bá ná meéle lósie" to mean: the power of the amulet has gone.

It is only at that moment that the guilty may initiate treatment by any traditional doctor, holder of traditional knowledge. It should be noted here that, according to the Banen the diseases that can be caused by amulets are difficult to treat with modern medicine.

\section{DISCUSSION}

\section{Diversity of Plants Used for Amulets in Banen Society}

The Banen people have a well established tradition of using plants in making amulets. Globally, this use of herbal amulets is reported in several studies across the world (Budge, 1899; Cabaton, 1909; Catherinet, 1954; Dennys, 1867; Dumas-Champion, 1997; Hoffmann-Krayer et al., 1927-1942; Settimi, 2010). These studies reported considerable number of plants currently used as amulets worldide in the forms of incense, powder, worn in a bag, or other assemblages including: Aloe buettneri Berger, Allium sativum L., Anthemis tinctoria E. C. Buxton, Anthemis vulgaris Fl. Dan. ex Steud., Chrysanthemum vulgare (L.) Bernh, 
Cissus quadrangularis Linn., Cichorium intybus L., Lavandula angustifolia Mill., Mentha pulegium L., Ocimum basilicum L., Origanum dictamnum L.; Plantago lanceolata L., Rosmarinus officinalis L., Verbena officinalis L., etc,.). In all societies of the world, whatever their religious orientations are, people use all kinds of amulets: plants, animals or animal remains, minerals, jewelry, signs, objects, pictures from the holy Bible, the cross, the verses of the Coran, oral sentences or words printed on paper, canvas, blades or metal plates. In Spain for example, such connection between popular religious and magic beliefs and their relationship with nature, especially plants was investigated by Gonzalez et al. (2012). They reported the traditional use of plants hung behind doors of houses and stables to repel witches, and rituals for curing evil eye affecting people, animals, or even possessions.

In sub-saharian Africa, Gruca et al. (2014) reported about 12 palm species in sub-Saharan Africa involved in various ritual practices including: Borassus aethiopum, Cocos nucifera, Dypsis canaliculata, D. fibrosa, D. pinnatifrons, Elaeis guineensis, Hyphaene coriacea, $H$. petersiana, Phoenix reclinata, Raphia farinifera, $R$. hookeri, and $R$. vinifera.

The plants recorded in this study are also reported in several studies for their ritual uses. Aframomum melegueta, apart from being sold as remedies at medicinal plant markets across sub-saharian Africa, is also reported to be used in ritual ceremonies. In Benin, they are used to enhance the effectiveness of medical treatments (Quiroz, 2015). The seeds are simply chewed fresh as ceremonial stimulants or to increase the power of ceremonial healing treatments. It is believed in Benin that Aframomum melegueta seeds 'increase the power of words', in a way that someone's promise to achieve a goal would gain more weight after eating the seeds of these plants.

Quiroz (2015) also reported the use of Cissus aralioides as protective baths against evil spirits in Gabon, Costus afer being planted in protection against Sorcerers in Benin, Euphorbia kamerunica being planted to protect fields and homes from sorcerers in Benin, Imperata cylindrical used as protection against sorcerer in Benin, Penthaclethra macrophylla used for good luck in Gabon, for divination and in protection against thieves in Benin and for protection against weapons and accidents in Gabon.

\section{Perception of Amulets by the Populations}

In Banen society, it is believed that plants can fix and transfer power to those who make amulets. This power is filled with mystical properties transmitted by ancestral tradition. This common view of herbal amulets was also reported in studies carried out in other locations (Lesoeurs, 2002). It should be noted that, the rituals in the process of making amulets are imperative; like the words pronounced, the odd number of leaves, shape or fragrance of the plant, symbols etc.

All the Banen people not only recognized inventoried plants as a component of the amulet, but they also collectively own this traditional knowledge, whether they are young, old, male or female. The metropolitan inhabitants were all able to give the function and the local name of the plant, but without identifying it, despite the fact that they are away from their natural environment, in the heart of mixing of populations and at the crossroads of globalization. They probably keep this traditional practice because they have received information from their parents, or not wanting to put themselves in compromised position, for reasons of self-censorship, respect, and love of their culture.

Among Banen people, the amulet is not only able to protect against evil spirits or bad influences when placed on a door or suspended from an object, it can also provide good luck, family prosperity, female fertility and increase the power of the dignitary. This is also the case of the Marba and Masa people in Tchad, the Dowayo, Fali, Koma, Kotoko, Lélé, Mofu, Mundang, Musey, Sara and the Yambassa people in Cameroon (Fourneau, 1935; Dumas-Champion, 1997).

For the Banen people, hanging the amulet on an object or putting it in compound indicates that object or place is strictly prohibited. The amulet should not be touched and it should not be looked at with dishonest eyes. An amulet is perceived as something dangerous that draws respect and fear. It is a symbol of moral, physical and psychological suffering to a person who transgresses its prohibition. The amulet has a defensive power, evil and aggressive action against any enemy that attempts to capture what the amulet has been adjured to protect.

\section{CONCLUSION}

The ethobotanical study of useful plants (for protection and autonomously organized justice) to the Banen people of the region of Ndiki aims to identify plants that are used as amulets. These amulets are adjured to protect people and their property, inflict sentiments of respect and fear and place them beyond legal power, according to perceptions and experiences among local people. A total of 11 species from 11 families involved in the confection of amulets by local people have been identified. 
Research indicates that amulets in general and herbal amulets in particular exist in all societies of the world. It is also documented that amulets are used universally throughout every time period. There is confidence in these various objects of worship or veneration because people believe they have supernatural powers. Although there is a wide spectrum of amulets across the world, the plants and purposes of the Banen people are different than those in other parts of the world.

With the deterrent measures of the amulet, the Banen people have developed a strategy to better educate their offspring by providing noble values namely: respect for others' goods, the virtues of working hard, preserving peace, harmony and cohesion among the community. Amulets extend beyond legal power and are a means of autonomously organized justice, according to the perceptions and experience of the respondents.

In the process of amulet confection, indigenous knowledge on biodiversity has been transmitted orally for centuries. Identification and documentation of useful plants in the Tunen language will help preserve this knowledge for future generations and facilitates future research projects in the region. This survey comes to value traditional African culture in general and that of the Banen people in particular.

\section{REFERENCES}

BETTI, J. L. 1994. Contribution à la connaissance des plantes médicinales dans la réserve de faune du Dja (Cameroun). Diseration Thesis. Université de Dschang.

BETTI, J. L. and LEJOLY, J. 1999. Importance en médecine traditionnelle de Combretum mucronatum Shum. \& Thon (Combretaceae) dans le Dja (Cameroun). In: NASI, R., AMSALLEM, I. and DROUINEAU, S. Eds. La gestion des forêts denses africaines aujourd'hui. Actes du séminaire FORAFRI de librevilleSession 3: produits de la forêt. Liberville, Gabon, pp. 1-16.

BERLIN, B. 1992. Ethnobiological classification: Principles of categorizations of plants and animals in traditional societies. Princeton: Princeton University Press.

WALLIS BUDGE, E. A. W. 1899. Egyptian magic. London.

WALLIS BUDGE, E. A. W. 1893. The Mummy: Chapters on Egyptian Funeral Archceology. Cambridge.

BHUIYAN, P., KHATUN, Z., JAHAN, S., MORSHED, T., RAHMAN, S., ANIK AFSANA, N., NASRIN, D. and RAHMATULLAH, M. 2013. Use of Quranic verses, amulets, numerology, and medicinal plants for treatment of diseases: a case study of a healer in Narsinghdi district, Bangladesh. AmericanEurasian Journal of Sustainable Agriculture, 7(5): 415-425.

CABATON, A. 1909. Amulettes chez les peuples islamisés de l'Extrême-Orient. Revue du monde musulman, 8(7): 369-397.

CATHERINET, M. 1954. Quelques rites agricoles chez les Banma-Kolon et les Maba de la région du Logone (Tchad). Notes Africaines, 62: 40-42.

CARRIERE, S. and MCKEY, D. 1999. Les arbres orphelins des champs vivriers. Etude de l'abattage sélectif chez les Ntumu et son impact sur la régénération de la forêt du sud-Cameroun. In: BAHUCHET, S., BLEY, D., PAGEZY, H. and VERNAZZA-LICHT, N. (Eds.). L'homme et la forêt tropicale. Société d’Écologie Humaine, pp. 255-266.

CHEVALIER, A. 1937. Les plantes magiques cultivées par les noirs d’Afrique et leur origine. Journal de la société des Africanistes, 7(1): 93-105.

COTTON, C. M. 1996. Ethnobotany: Principles and Applications. Chichester: John Wiley and Sons.

DENNYS, N. B. 1876. Folklore of China and Its Affinities with that of the Aryan and Semitic Races. London: Trübner.

DJOTSA, A. B. S. 2002. Dynamique des contacts forêts-savanes: Flore et végétation de trois savanes périforestières. Mémoire de DEA. Université de Yaoundé.

DUMAS-CHAMPION, F. 1997. A propos du couple Cissus quadrangularis/Aloe buettneri Berger. In: Les hommes et le milieu végétal dans le bassin du Lac Tchad. Paris: ORSTOM, pp. 339-347.

DOUNIAS, E., BAHUCHET, S., FROMENT, A. and DE GARINE, I. 1998. Connaissance et utilisation de l'environnement par les sociétés du Centre du Cameroun dans l'écotone Forêt-Savane. In: Systèmes écologiques et actions de l'homme. Paris: CNRS, Programme "Environnement, Vie et Sociétés", pp. 189-196.

FOURNEAU, J. 1935. Le néolithique au Cameroun: Les haches de pierre polie de Bafia et leur signification dans les societies indigenes actuelles. Journal de la Société des Africanistes, 5(1): 67-84.

GAUTIER, L. 1992. Contact forët-savane en Côte d'Ivoire Centrale: rôle de Chromolena odorata (L) king et Robinson dans la dynamique de la végétation. PhD. Thesis. Université de Genève.

GONZALEZ-WIPPLER, M. 1991. Complete Book of Amulets \& Talismans. Sourcebook Series. St. Paul, MN: Lewellyn Publications. 
GONZÁLEZ, A. J., GARCÍA-BARRIUSO, M., PARDO-DE-SANTAYANA, M. and AMICH, F. 2012. Plant Remedies against Witches and the Evil Eye in a Spanish “Witches' Village”. Economic Botany, 66(1): 35-45.

GRUCA, M., VAN ANDEL, T. R. and BALSLEV, H. 2014. Ritual uses of palms in traditional medicine in sub-Saharan Africa: a review. Journal of Ethnobiology and Ethnomedicine, 10: 60.

HOFFMANN-KRAYER, E. and BÄCHTOLD-STÄUBLI, H. 1927-1942. Handwörterbuch des deutschen Aberglaubens. 10 Volumes. Berlin: Walter de Gruyter.

HUMAYUN, M., KABIR, N. H., MAHFUJUR, R., ASHIKUR, R., JAKIA, A. K., NAZIA, T. H., RUHUL, Q. B., SADIA, M. O. and MOHAMMED, R. 2013. Tribal medicine in tribes who have lost their identities: Medicinal plants of tea garden workers in Sreemangal, Maulvibazar district, Bangladesh. AmericanEurasian Journal of Sustainable Agriculture, 7(4): 251-258.

IYEBI-MANDJEK, O. 1985. L'évolution du système agraire en pays Banen. PhD. Thesis. Université de Yaoundé.

JOHNSON, M. 2017. Plantes et rites sacrificiels chez les Banen du Cameroun: Crinum zeylanicum L. comme expression de la culture. Yaoundé: Éditions CLÉ; Bafoussam: CIPCRE.

JOHNSON, M. 2013. Diversität und Nutzung der Flora bei den Banen in Kamerun. Südwestdeutscher Verlag für Hochschulschriften.

KEAY, R. W. J. 1989. Arbres nigérianes. Oxford: Claredon Press.

LESSOEURS, G. 2002. Surnaturel magique: Plantes entrant dans la composition des talismans et amulettes utilisés pour conjurer les maladies en France. In: FLEURENTIN, PELT, J.-M. and MAZARS, G. Des sources du savoir aux médicaments du futur. Marseille: Société française d'ethnopharmacologie, pp. 443-448.

LETOUZEY, R. 1985a. Notice de la carte phytogéographique du Cameroun, au 1:500 000, TV: Domaine de la forêt dense humide toujours verte. P 95-142 avec groupement No 185-267. Yaoundé: Institut de la recherche agronomique.

LETOUZEY, R. 1985b. Notice de la carte phytogéographique du Cameroun, au 1:500 000, TV: Domaine de la forêt dense humide toujours verte. P 95-142 avec groupement No 136-184.

LETOUZEY, R. 1985c. Notice de la carte phytogéographique du Cameroun, au 1:500 000, S-S: Domaines sahélien et soudanien. P 1-26 avec groupement No 1-103. Yaoundé: Institut de la recherche agronomique.

LETOUZEY, R. 1985d. Notice de la carte phytogéographique du Cameroun, au 1:500 000,M-SM: Région afro-montagnarde et étage submontagnard. P 27-62 avec groupement No 104-135. Yaoundé: Institut de la recherche agronomique.

LETOUZEY, R. 1985e. Notice de la carte phytogéographique du Cameroun, au 1:500 000, B-1: Bibliographie et index des noms scientifiques P 143-240. Yaoundé: Institut de la recherche agronomique.

LETOUZEY, R. 1970 Manuel de botanique forestière, Afrique Tropicale. Tome 2. Sainte Marie. France: CTFT.

LETOUZEY, R. 1968. Eude phytogéographique du Cameroun. Paris: Paul Lechevalier.

MAHEND BETIND, P. L. 1963. Rites et croyances relatifs à l'enfance chez les Banen du Cameroun. Thèse de licence. Paris 14e: Faculté libre de Théologie Protestante.

MALEY, J. 2001. La destruction catastrophique des forêts d'Afrique centrale survenue il y a environ 2500 ans exerce encore une influence majeure sur la répartition actuelle des formations végétales. Systematics and Geography of Plants, 71: 777-796.

MALEY, J. 1997. Variation à long terme des écosystèmes forestiers du sud Cameroun et du Gabon au cours des derniers millénaires. In: Actes du Séminaire FORAFRI de Libreville-Session 2: connaissance de l'écosystème. Libreville (GAB), 1998/10/12-16.

NJUPOUEN. B. R. 2005. Access to justice for the poor what role for bar associations? The case of Cameroon. A Dissertation submitted in partial fulfilment of the requirement for the award of the Master of Science in Governance and Development Management. Birmingham: University of Birmingham.

PASCUAL, U., BALVANERA, P., DÍAZ, P. et al. 2017. Valuing nature's contributions to people: the IPBES approach. Current opinion in environmental sustainability, 26-27: 7-16.

PIERONI, A., ELENA GIUSTI, A. and CASSANDRA, L. Q. 2011. Cross-Cultural Ethnobiology in the Western Balkans: Medical Ethnobotany and Ethnozoology Among Albanians and Serbs in the Pešter Plateau, Sandžak, South-Western Serbia. Human Ecology, 39: 333-349.

QUIROZ, D. 2015. Do not fear the supernatural! The relevance of ritual plant use for traditional culture, nature conservation, and human health in western Africa. PhD Thesis. Wageningen University.

SETTIMI, F. 2010. L'ail, une plante aux multiples vertus. Available at: www.heds-ge.ch/diet/encyclopedie/ ail_10.pdf. [Accessed: 2020, January 15].

THIRAKUL, S. 1983. Manuel de dendrologie, Cameroun. Québec, Canada: Groupe Poulin, Thériault Ltée. 
VIVIEN, J. and FAURE, J. J. 1985. Arbres des forêts denses d'Afrique Centrale. Ministère des relations extérieures. Paris: Coopération et Développement, ACCT.

WILKS, C. M. and ISSEMBE, Y. 2000. Guide pratique d'identification des arbres de la guinée équatoriale, région continentale. Projet CUREF Bata Guinée Equatoriale.

Contact information

Madeleine Johnson: maajohson@yahoo.fr Evariste Fongnzossie: fongnzossie@gmail.com 


\section{APPENDIX}

Appendix A: Plants used in making amulets among the Bane and aspect of amulets

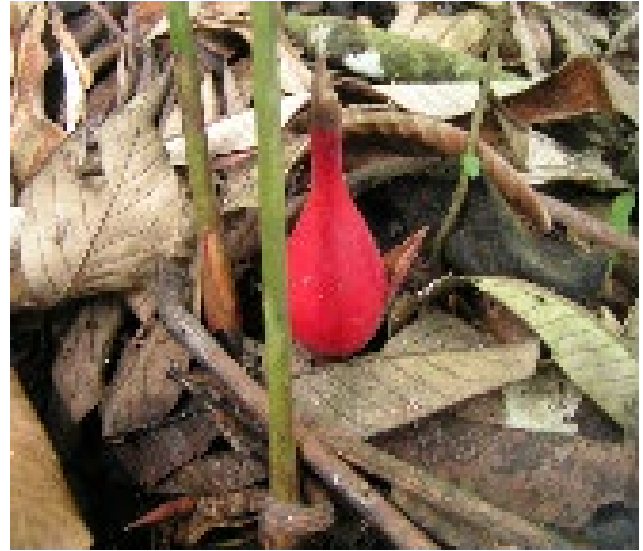

1: Aframumum melegueta

Source: Johnson, present survey

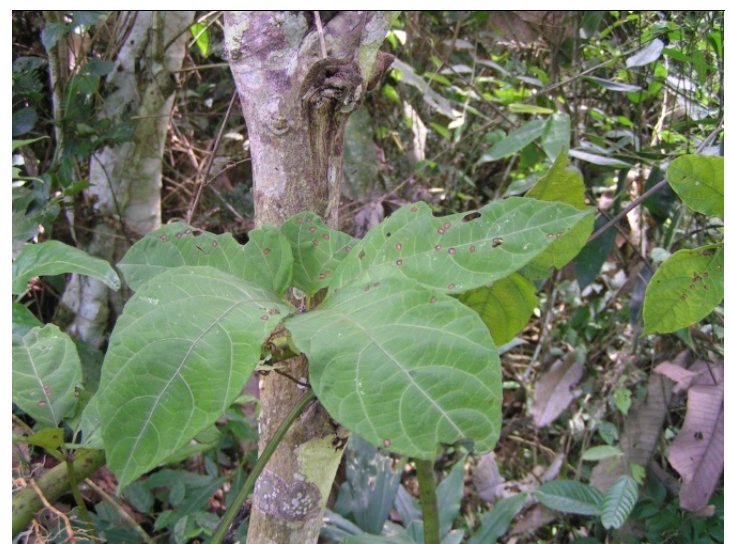

3: Cissus aralioides

Source: Johnson, present survey

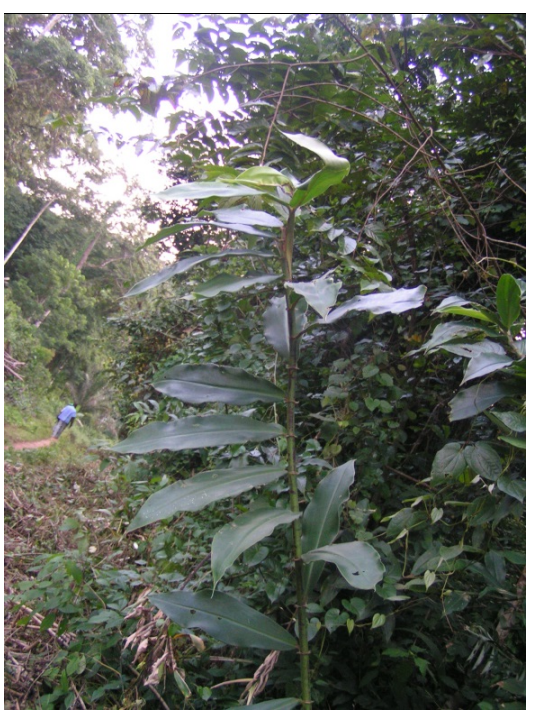

5: Costus afer

Source: Johnson, present survey

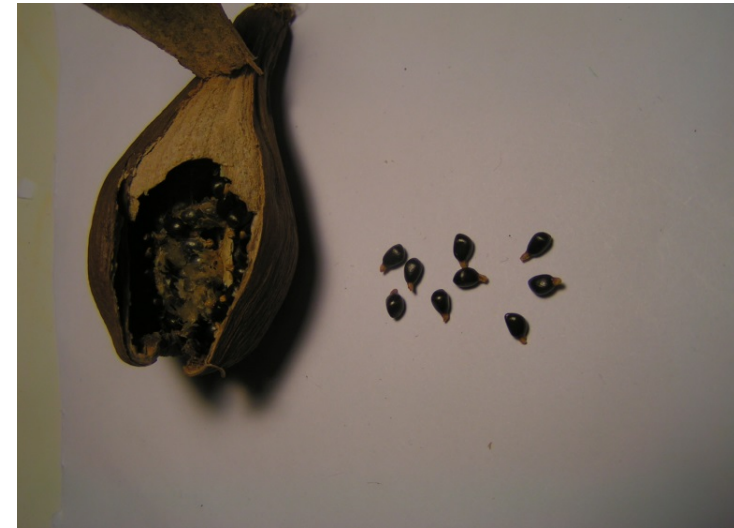

2: Seeds of A melegueta used to empower all amulets Source: Johnson, present survey

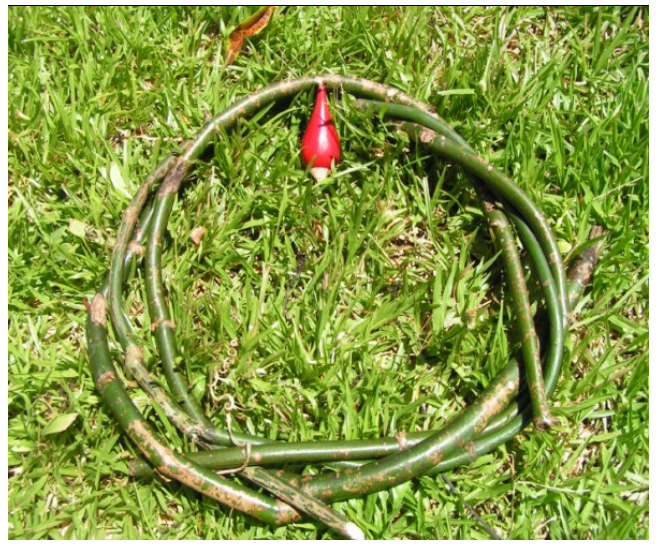

4: Amulet from vines of Cissus aralioides Source: Johnson, present survey

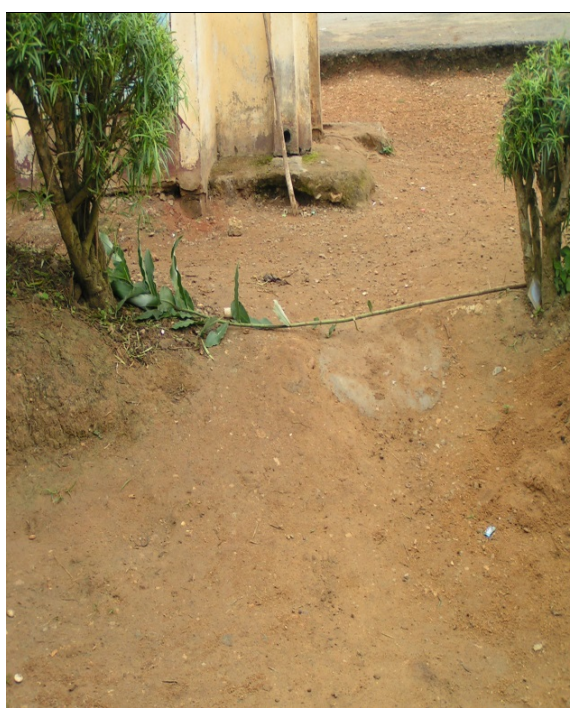

6: Amulet of Costus afer placed at home entrace Source: Johnson, present survey 


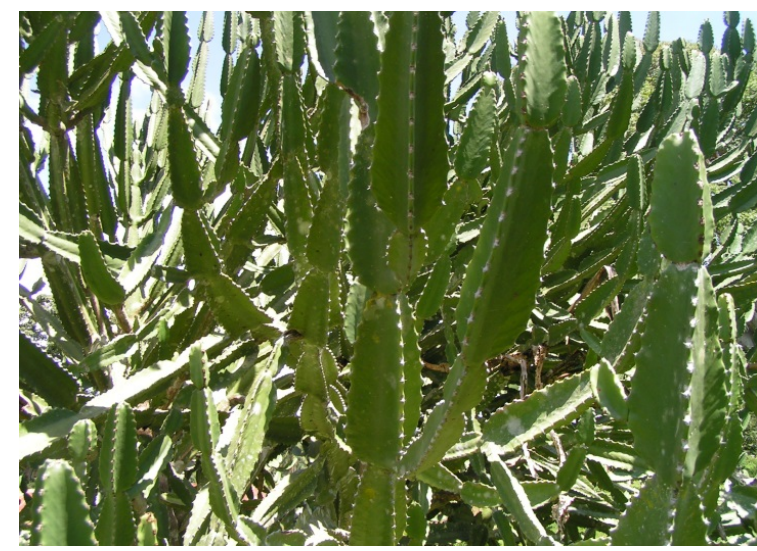

7: Euphorbia kamerunica

Source: Johnson, present survey

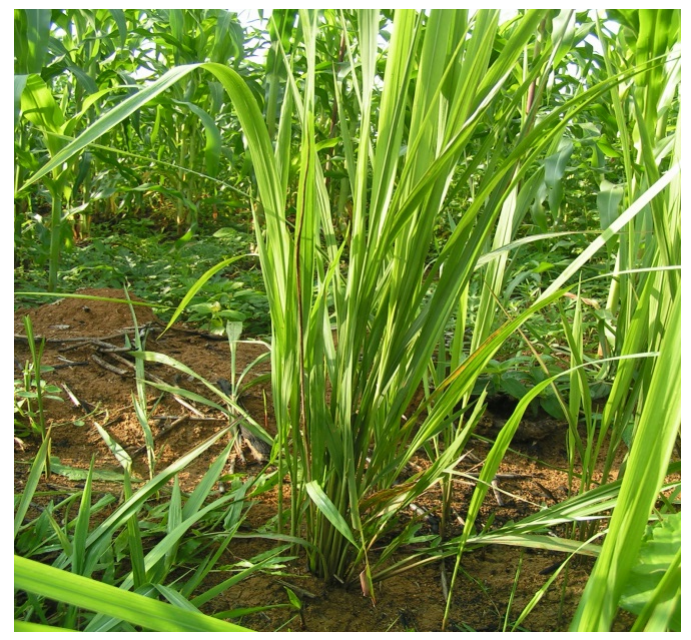

9: Imperata cylindrica Source: Johnson, present survey

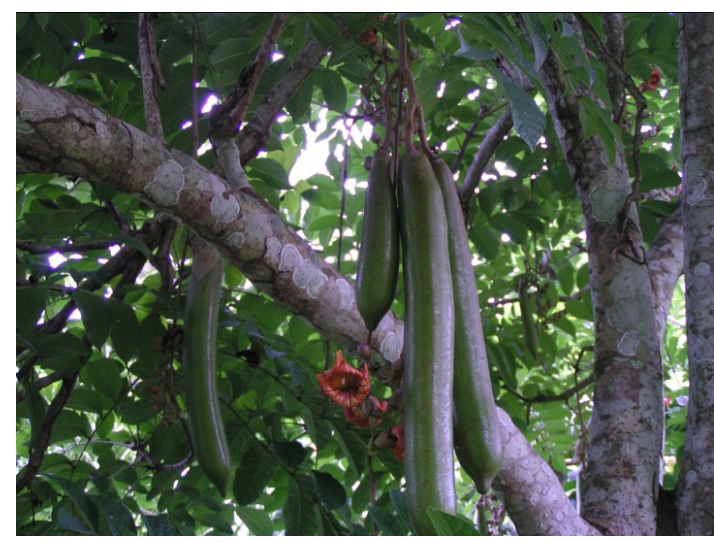

11: Kigelia africana tree Source: Johnson, present survey

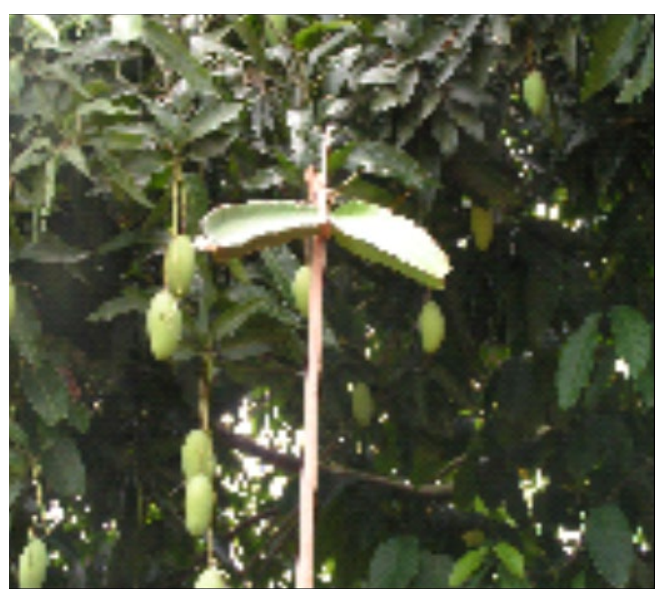

8: Aspect of E. kamerunica amulet placed on a mango tree

Source: Johnson, present survey

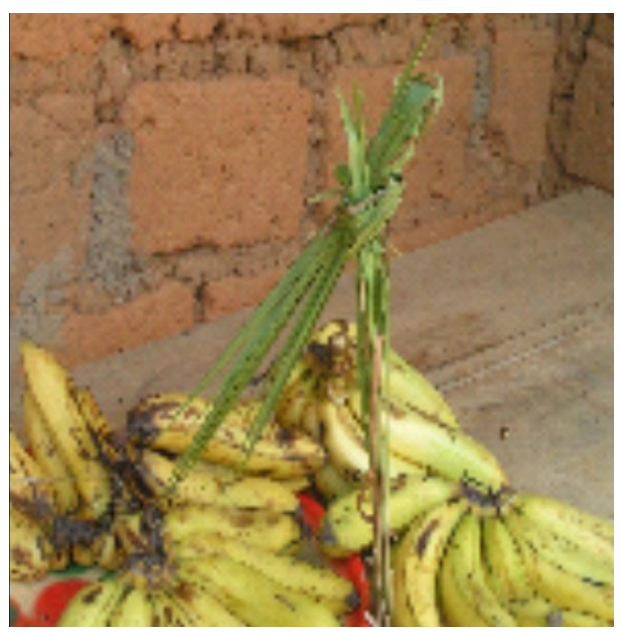

10: Amulet from I cylindrica used to protect goods Source: Johnson, present survey

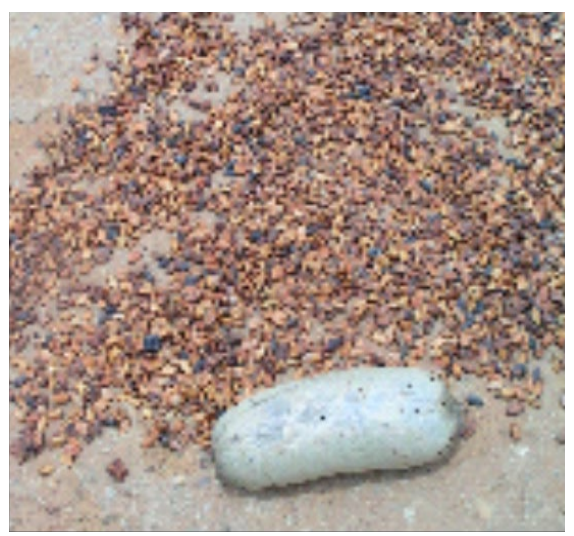

12: Amulet from K. africana used to protect goods

Source: Johnson, present survey 


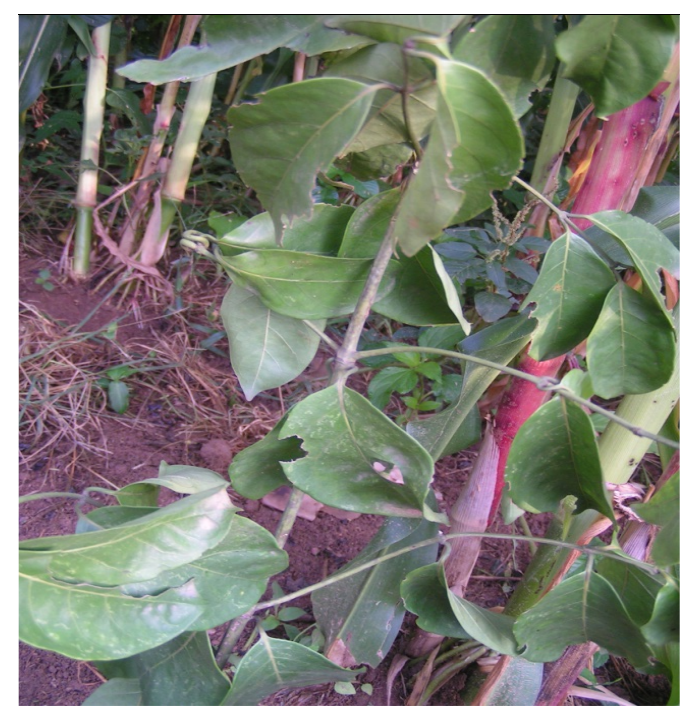

13: Morinda morindoides

Source: Johnson, present survey

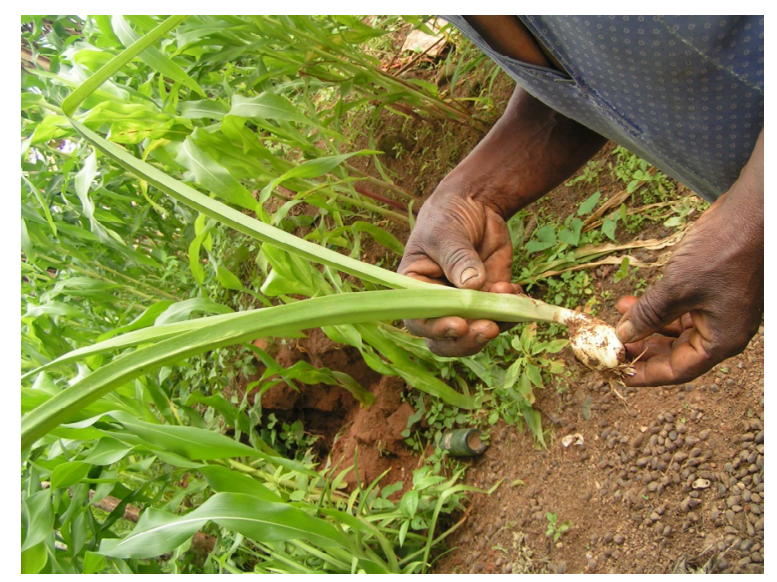

15: Ornithogalum sp planted as a protection of fields of homes Source: Johnson, present survey

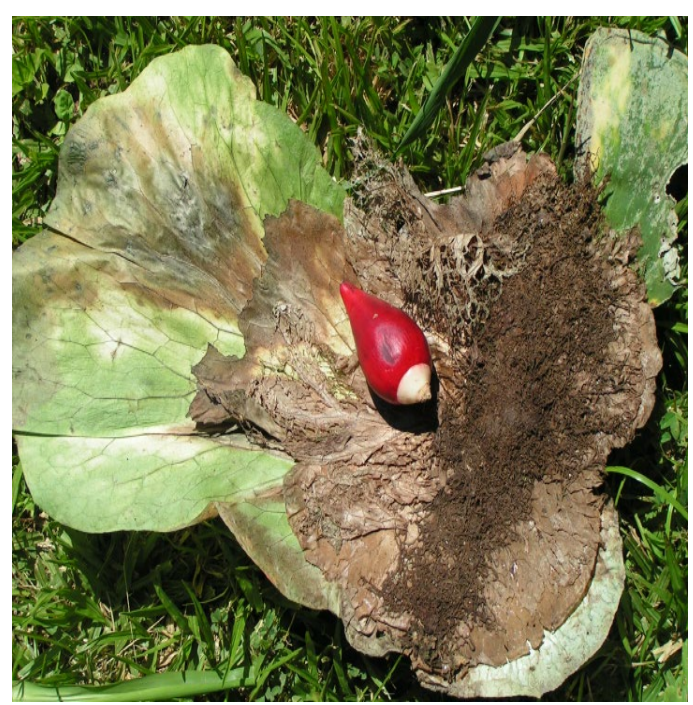

17: Amulet from Platycerium angolense (the red fruit on top is A melegueta)

Source: Johnson, present survey

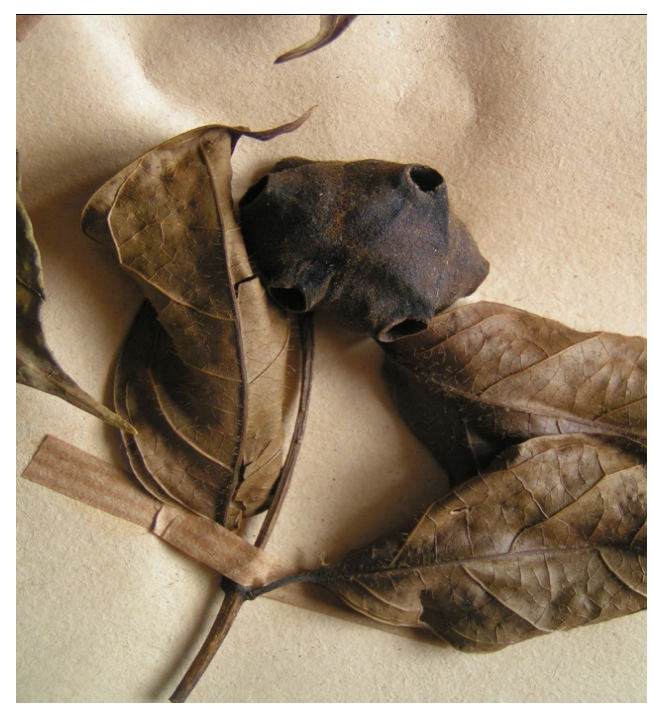

14: Amulet from M. morindoides

Source: Johnson, present survey

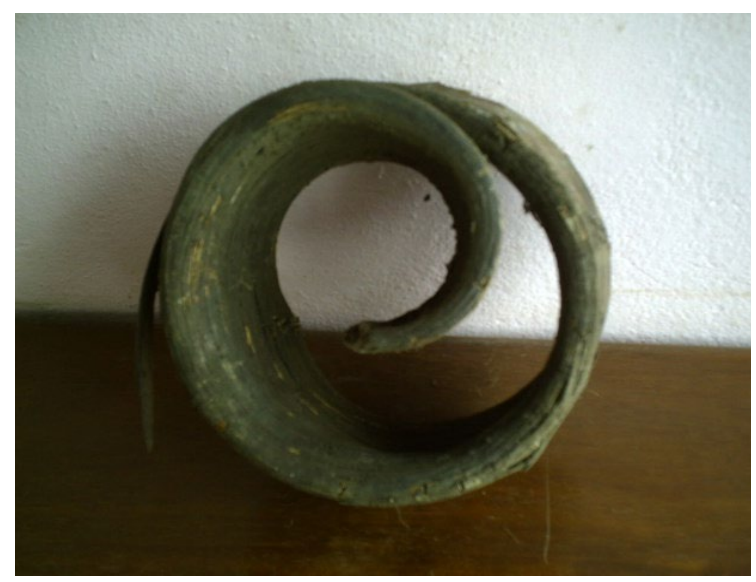

16: Amulet from empty pods of Pentaclethra macrophylla Source: Johnson, present survey

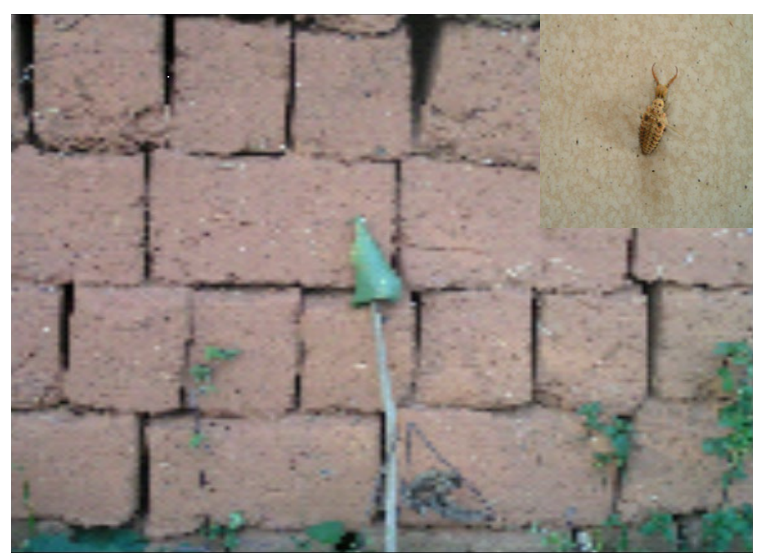

18: A funel-shape leaf of Trachyphrynium braunianum used as amulet to protect compounds Source: Johnson, present survey 